\title{
Ways to improve the Romanian teachers' occupational prestige. \\ A systematic literature review
}

Diana-Crina Marin, Cecilia Macri 


\title{
Ways to improve the Romanian teachers' occupational prestige. A systematic literature review
}

\author{
Diana-Crina Marin ${ }^{a *}$, Cecilia Macri $^{\mathrm{b}}$ \\ ${ }^{a}$ Faculty of Psychology and Educational Sciences, Babeş-Bolyai University, 7 Sindicatelor Street, 400015, Cluj-Napoca, Romania \\ ${ }^{b}$ Bucharest Center of Educational Resources, Romania \\ *Corresponding author: Diana.PANCU@ubbonline.ubbcluj
}

\section{Abstract}

\section{Keywords:}

teachers' occupational prestige, self-esteem, motivation, professional satisfaction, schoolfamily-communitypartnership
Recent research has revealed that teachers' occupational prestige has become lower during the last years. The purpose of this study was to establish which are the strategies that could be applied in order to improve the teachers' prestige. At the same time, we were interested in establishing which are the main factors that contribute to the decreasing of the professional prestige of the teachers and to present the ameliorative solutions identified by us, taking into account the opinion of the researchers from Romania who have conducted researches on this topic. Some of the most important measures are related to reducing bureaucracy, stability, predictability and adequate funding of the educational system, improving teachers' working environment, and maintaining effective interpersonal relationships with students, parents, colleagues, school managers, and other educational agents. Love for teaching and the desire to contribute actively to the harmonious development of the current generation of children are some of the positive implications of this profession, which bring satisfaction to the teachers.

\section{Schlüsselworte:}

Beschäftigungansehen der Lehrer,

Selbstwertschätzung,

Motivation, berufliche Zufriedenstellung,

Partnerschaft Schule-

Familie-Gemeinschaft
Die jüngsten Erforschungen haben gezeigt, dass das Beschäftigungsansehen der Lehrer in den letzten Jahren gesunken ist. Zweck dieser Studie war festzulegen, welche die Strategien sind, die dürfen angewandt werden, um das berufliche Ansehen der Lehrer zu verbessern. Zugleich haben wir uns vorgenommen, festzulegen, welche die Hauptfaktoren sind, die zur Minderung des Beschäftigungsansehens der Lehrer beigetragen haben, und die von uns identifizierten verbessernden Lösungen darzulegen, indem wir die Meinung der Forscher aus Rumänien berücksichtigen, die Erforschungen zu diesem Thema durchgeführt haben. Einige der wichtigsten Massnahmen stehen mit der Reduzierung der Bürokratie, der Verbesserung des Arbeitsumfeldes der Lehrer, der angemessenen Standfestigkeit, Vorhersehbarkeit und Finanzierung des Bildungssystems, sowie der Aufrechterhaltung einiger wirksamer zwischenpersönlicher Beziehungen mit den Studenten, Eltern, Kollegen, Schulmanagern und weiteren Bildungsagenten in Verbindung. Die Liebe für den Lehrerberuf und der Willen dazu, aktiv zur harmonischen Entwicklung der aktuellen Kindergeneration beizutragen, stellen einige der positiven Implikationen der Ausübung dieses Berufs dar, die die Lehrer zufriedenstellen.

\section{Introduction}

Mass-media usually presents various situations that indicate several problems of the current educational system, including the fact that the confidence of the members of the society has decreased during the last years. We consider that a high-quality occupational prestige of the teachers is associated with positive attitudes of the members of the society, trust, and valorization of the systematic efforts of the teachers in order to offer the best educational opportunities for each child.

\section{Theoretical foundation}

The high quality of the educational processes, a positive learning environment, the motivation for learning and the respect for others, including for parents and teachers, are some of the factors which influence the children's development in a positive manner. All the members of the society should respect the teachers' profession and the values promoted by the educational institutions. "The way teaching staff evaluate the social prestige of their profession fulfils normative and motivational functions and is, hence, reflected in how they actually perform their professional roles, serving both explicative and prospective purposes." (Frunzaru \& Dumitriu, 2015, p. 629). According to Buzea \& Scârneci 
(2011, p. 17), "the issue of occupational prestige is subscribed to the individual axiological system". The study conducted by Andronache, Bocoș, Bocoș \& Macri (2014, p. 632) revealed that "the behavioral manifestations of attitude towards the teaching profession may be directly influenced and dependent on context. Moreover, contextualized experiences become important, in the sense that not only the context itself may influence the manifestation of attitude but also subjective experiences of individuals, determined by relative context".

The results of the research carried out in Romania highlight the fact that the teachers' self-prestige had a negative evolution (Frunzaru \& Dumitriu, 2015; Gheorghe, 2017; Marin \& Bocoș, 2018). The research conducted by Frunzaru \& Dumitriu (2015) revealed that some of the strategies that could be applied in order to improve the self-perceived occupational prestige of the teachers are: eliminating the bureaucracy, consolidating the school-family-community partnership, developing effective relationships with students, parents, colleagues and school managers, and adequate funding of educational institutions. The study conducted by Marin \& Bocoș $(2018$, in press.) revealed that, in the view of the school principals, public policies should be adopted, in order to improve the prestige of the primary school teachers and of all other categories of educators. A public policy is a set of governmental decisions elaborated with the purpose of generating positive effects on a matter of great interest (Fink, 2016). Gheorghe (2017) show that the negative feedback received by the teachers from the members of the society could negatively influence their self-esteem and the quality of their didactic activity. "The teachers' perceptions of their own job are significantly influenced by the environmental factors, such as the teacher-student relationship, the collaboration between teachers or the systems of feedback and evaluation". Another important aspect revealed by the research conducted by Gheorghe (2017) is that there is a negative correlation between the volume of work and professional responsibilities of the teachers and the level of their selfesteem. "The more sense of freedom school gives teachers, the higher job satisfaction, and the lower burnout teachers will have." (Jiang, 2005, p.73).

The teachers from urban areas are more satisfied with their current professional status than teachers from rural areas (Gheorghe, 2017). The relationship established "with both school management and pupils' parents are important predictors for the self-perceived level of occupational prestige" (Frunzaru \& Dumitriu, 2015, p. 639). Xiaofu and Qiwen (2007) considered that an effective management of the educational institutions is associated with a high self-esteem and satisfaction of the employers. "School climate has changed, it has become more tense, cold, and stressful. Relationships are mostly collegial and there are less friendships; these relationships are more reserved, more prudent, more suspicious and less opened, emphatic, trustful. It looks like their fear for losing their job and the many criteria which are difficult to accomplish negatively affect collegial relations and school atmosphere" (Mărgărițoiu \& Eftimie, 2013, p. 114). According to Anghelache (2014, p. 53) "motivation for the teaching career seems to increase with the subjects' ageing" and the persons aged between "18 and 28 are less interested in the teaching profession, because of the low income and the low social status of this job". According to Bentea \& Anghelache (2012, p. 171) "teachers who think that the teaching profession is largely based on moral responsibility and social importance, work quality and efficiency, and has a motivating potential for them, have higher levels of job satisfaction too, and conversely".

\section{Research methodology}

We have conducted a systematic review of the literature in order to establish which are the factors and solutions proposed by the researchers from Romania in order to improve the prestige of the teachers. The inclusion criteria used in order to select relevant research articles and studies concerning this research topic are presented below. The publications must be written in Romanian or in English, during the last 10 years. We have used the following keywords: "Teachers' Prestige", "Job satisfaction" and "Romania". Peer review journal articles and conference proceedings were the types of publications used in order to realize this systematic review of the literature. We have consulted the following electronic databases: ProQuest Central and ScienceDirect. In the eligibility phase, 3 full-text articles were excluded, leaving a total of 9 eligible studies to be included in the qualitative synthesis (see Figure no. 1). All the articles that were not related to our research questions or were related to the aspects regarding the university level were excluded.

Our investigation was oriented towards the following questions: 
- Which are the factors that contribute to the decreasing of the prestige of the pre-university teachers?
- Which are the institutional measures/ public policies that could be adopted in order to improve the preuniversity teachers' occupational prestige?
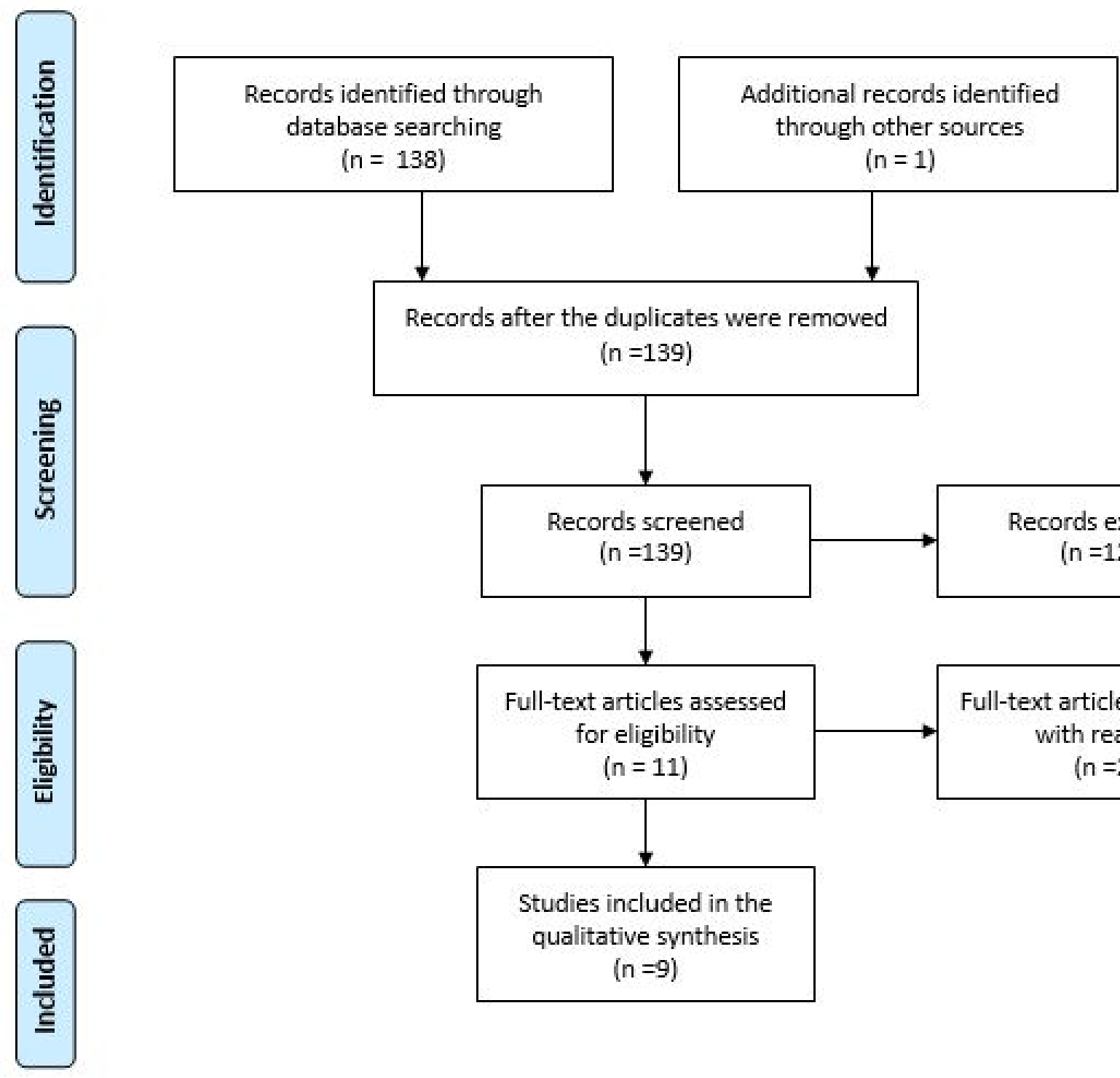

Records after the duplicates were removed $(n=139)$

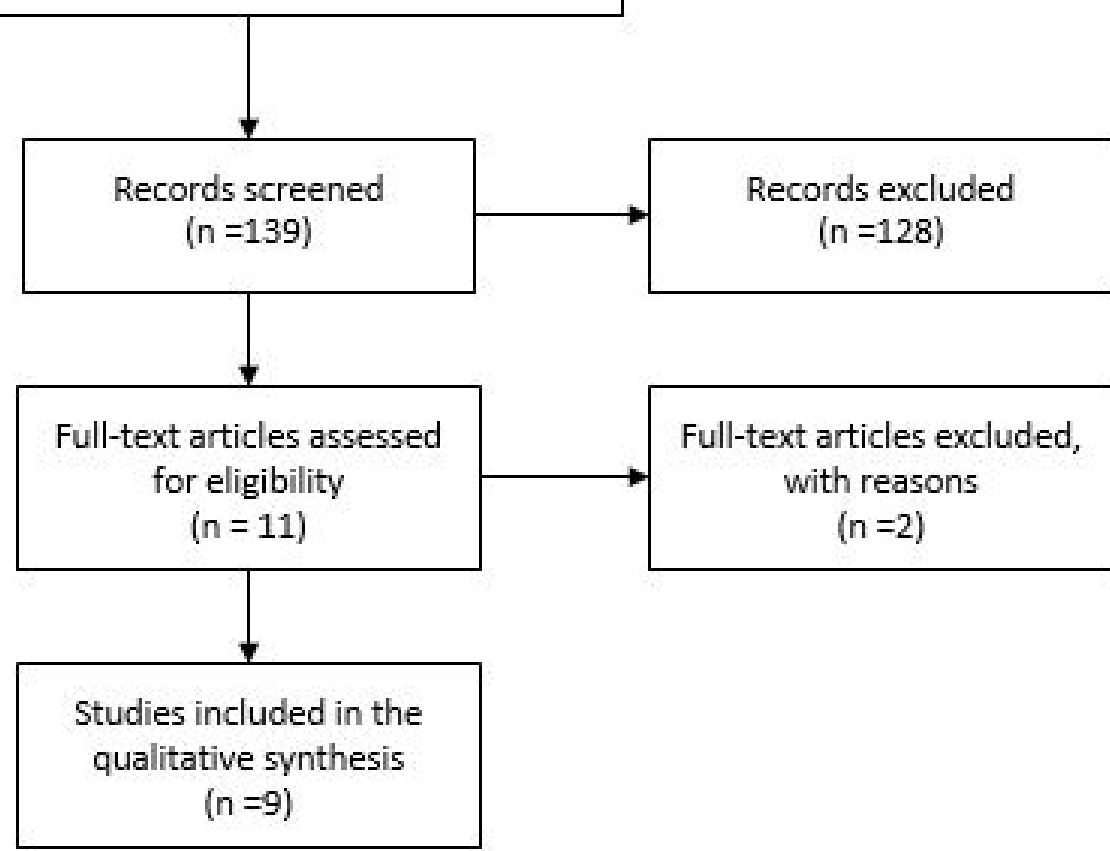

Figure no. 1. PRISMA Flow Chart for the selection process of the articles concerning the teacher's level of occupational prestige and satisfaction (Moher, Liberati, Tetzlaff, \& Altman, 2009)

\section{Results}

All the studies identified by us highlight that the teachers' prestige had a negative evolution during the last period of time. Table 1 includes the main factors and ameliorative solutions proposed by the researchers from
Romania, interested in this topic (Mărgărițoiu \& Eftimie, 2013; Popescu \& Tudorache, 2014; Frunzaru \& Dumitriu, 2015; Anghelache, 2014; Gheorghe, 2017; Alexandrache, 2015; Șerbănescu \& Popescu, 2014; Bentea \& Anghelache, 2012; Stan, 2015). 
Table no. 1. Measures that could be adopted in order to improve the teachers' occupational prestige

\begin{tabular}{|c|c|}
\hline $\begin{array}{c}\text { Signs that indicate a low level of the teacher's } \\
\text { prestige }\end{array}$ & es to increase teachers' \\
\hline $\begin{array}{l}\text { - the occurrence of conflicts between parents and } \\
\text { teachers; } \\
\text { - a low level of confidence between parents and } \\
\text { teachers; } \\
\text { - the decision of some of the teachers to leave the } \\
\text { educational system by choosing other domains of } \\
\text { activity; } \\
\text { - a high level of bureaucratic tasks; } \\
\text { - teaching a high number of students } \\
\text { simultaneously; } \\
\text { - teachers' dissatisfaction with their own status; } \\
\text { - the instability of the educational system and the } \\
\text { educational reform, which is too often renewed; } \\
\text { - the occurrence of stressful and complex } \\
\text { situations which the teachers should face while } \\
\text { practicing their profession; } \\
\text { - teachers dissatisfaction regarding their } \\
\text { incomes; } \\
\text { - lack of attractivity of the teacher's profession. }\end{array}$ & $\begin{array}{l}\text { - eliminating the bureaucracy; } \\
\text { - adequate funding for the educational system and } \\
\text { increasing the teachers' salaries; } \\
\text { - adapting the curriculum to the current demands of the } \\
\text { society; } \\
\text { - improving teachers' authority, working condition and } \\
\text { motivation for performing their daily attributions in good } \\
\text { conditions; } \\
\text { - coherence in the process of decision making and a high } \\
\text { level of stability of the educational system; } \\
\text { - creating an organizational culture based on trust, self- } \\
\text { respect, appreciation, and cooperation; } \\
\text { - consolidating the school-family-community partnership; } \\
\text { - a high level of professional training of each teacher; } \\
\text { - decreasing the number of pupils enrolled in classes in the } \\
\text { school institutions of Romania; } \\
\text { - valorizing the real potential of each student and creating } \\
\text { effective teacher-student relationships; } \\
\text { - adopting a democratic management type, based on } \\
\text { transparency, cooperation and involvement of the teaching } \\
\text { staff in the process of decision making. }\end{array}$ \\
\hline
\end{tabular}

It is important to outline that the measures and the strategies proposed during this study should be adopted at the level of the entire educational system and, at the same time, at the institutional level.

\section{Discussions}

Through this systematic literature review, we have decided to list some of the most efficient modalities to increase teachers' occupational prestige. Researchers from Romania suggested various solutions that could be applied in order to improve the teachers' prestige. The literature review conducted by us revealed that some of the most important measures are related to reducing bureaucracy, stability, predictability and adequate funding of the educational system, improving teachers' working environment, and maintaining effective interpersonal relationships with students, parents, colleagues, school managers, and other educational agents. Some of the solutions proposed by the Romanian researchers are related to changes at the entire level of the educational system. Some of them are related to gaining the authority and independence in practicing the teaching profession. Changes at the institutional level are important at the same time. The managerial policies based on respect, valorization, transparency, and cooperation in the process of decision-making have a positive impact on the self-image of the teachers. A democratic managerial style has beneficial effects on the entire activity of the educational institutions, and the valorization of the efforts 
made by all the educational partners ensure a positive climate and effective interpersonal relationships.

\section{Conclusions}

We consider that an increased level of prestige of the teachers contributes significantly to obtaining a high involvement of the family and of the community in the school life. At the same time, the attractiveness of this profession will be significantly increased if the educational prestige of the teachers perceived by educators and by all other members of the society is improved. In conclusion, the professional merits of the teachers should be outlined through various strategies, including mass-media. In this way, the students, the parents and all other members of the society will understand the high social importance of this occupation. In our opinion, the most important qualities of an efficient teacher who benefits of high prestige and social recognition are: responsibility, integrity, self-exigence, the desire for self-improvement, impartiality, respect for all the collaborators, a high level of self-esteem, and the most important fact, love for pupils and passion for their teaching activity.

\section{Authors note:}

Diana-Crina Marin is currently a teacher at Liceul Teoretic "Pavel Dan" Câmpia Turzii ("Pavel Dan" Theoretical High School of Câmpia Turzii) and Doctoral Student at Babeș-Bolyai University. Her research areas are aimed at discovering innovative modalities to consolidate the school-family partnership, considering that the school and family should be real partners in children's education. She is also interested in finding the most efficient teaching practices that could be successfully used in the educational process.

Cecilia Macri is logopedic teacher in Bucharest Center of Educational Resources. She has obtained a Ph.D. in Educational Sciences in 1997 at Babeș-Bolyai University. Her main study and research environment are consisted of the complex specificity of logopedic activity with preprimary and early primary students, including general teaching problems and the therapies for speech disorders.

\section{References}

Alexandrache, C. (2015). Occupational Stress as a Factor of (non) Orientation Teaching Profession. Procedia - Social and Behavioral Sciences , 180, 1038-1043.

Anghelache, V. (2014). Motivation for the Teaching Career. Preliminary Study, Procedia - Social and Behavioral Sciences, 128, 49-53.

Andronache, D., Bocoş, M., Bocoş, V. \& Macri, C. (2014). Attitude Towards Teaching Profession. Procedia - Social and Behavioral Sciences. 142, 628-632.

Bentea, C.-C., \& Anghelache, V. (2012). Teachers' Perceptions and Attitudes Towards Professional Activity. Procedia Social and Behavioral Sciences, 51, 167-171.

Buzea, F., \& Scârneci, C. (2011). Occupational Prestige in Romania - An Exploratory Study. Bulletin of the Transilvania University of Braşov, 4(53), 9-18.

Fink, J.W. (2016). Law, politics, and the creation of public policy: How the two can come together and create better public policy (Order No. 10167656). Available from ProQuest Central. (1845052639). Retrieved from https://search-proquest-com.am.e-

nformation.ro/docview/1845052639?accountid=134368.

Frunzaru, V., \& Dumitriu, D. (2015). Self-perceived Occupational Prestige among Romanian Teaching staff: Organisational Explicative Factors. Management Dynamics in the Knowledge Economy, 3(4), 629-643.

Gheorghe, O. (2017). Profesia de cadru didactic: statut social, responsabilități, satisfacții. Retrieved from https://iteach.ro/experientedidactice/profesia-de-cadrudidactic-statut-social.

Jiang, Y. (2005). The influencing and effective model of early childhood teachers job satisfaction in China, US-China Education Review, 2(11), 65-74.

Marin, D.-C., \& Bocoș, M. (2018, in press). School Principals' Opinion on the Strategies of Strengthening School-Family Partnership. Manuscript submitted for publication.

Mărgăriţoiu, A., Eftimie, S. (2013). Pre-university Teachers' Professional Satisfaction, Procedia - Social and Behavioral Sciences, 78, 110-114.

Moher, D., Liberati, A., Tetzlaff, J., \& Altman, D. G. (2009). Preferred reporting items for systematic reviews and metaanalyses: The PRISMA statement. PLoS Medicine, 6(7). https://doi.org/10.1371/journal.pmed.1000097.

Popescu, C., \&; Tudorache, A.-M. (2014). Motivational Specificities of Teachers in the Pre-university Education in Romania, Land Forces Academy Review, 19(3), 267-274.

Stan, M.-M. (2015) Study on the motivational variables and professional values in the Romanian academic environment, Procedia - Social and Behavioral Sciences, 180, 1661-1666.

Şerbănescu, L. \& Popescu, T. (2014). Motivation for the teaching career, Procedia - Social and Behavioral Sciences 127, 691-695.

Xiaofu, P., \& Qiwen, Q. (2007). An analysis of the relation between secondary school organizational climate and teacher job satisfaction, Chinese Education and Society, 40(5), 65-77. 